\title{
Pengaruh Kompensasi Finansial Dan Pengawasan Terhadap Kinerja Karyawan CV. YWN Motor Kampar
}

\author{
LAMIN \\ Sekolah Tinggi Ilmu Ekonomi Riau (STIER) \\ Jln. HR. Subrantas 57 Panam Pekanbaru 28293 Telp. (0761) 63237 \\ E-mail: akbar_stier@yahoo.com
}

\begin{abstract}
The sample in this research is all employees of CV. YWN Motor Kampar is 32 employees taken samples. Based on the results of research analysis obtained test results 1 that the value of $t$ arithmetic compared with t table result is $2.207>2.042$ and the significance of $0.03<0.05$ means partially financial compensation significantly affect employee performance. Result of test $2 \mathrm{t}$ arithmetic compared with t table result is 5,536>2,024 and significance value equal to $0,00<0,05$ meaning partially supervision have significant effect to employee performance. From ANOVA table, the value of $\mathrm{F}$ equal to 22,465 with probability value (Sig.) $=0,000$, because sig value $<0,05$ then the result is financial compensation and supervision together have a significant effect on employee performance $\mathrm{CV}$. YWN Motor with a magnitude of influence of $60.8 \%$.
\end{abstract}

Keywords: Financial Compensation, Supervision, Employee Performance

Manajemen sumber daya manusia merupakan pengaturan sumber daya manusia yang ada sebagai unsur penting dalam pencapaian tujuan organisai atau perusahaan dalam memperoleh keuntungan yang diinginkan dan juga merupakan suatu gerakan pengakuan terhadap pentingnya unsur manusia sebagai sumber daya yang cukup potensial dan sangat dominan pada setiap organisasi. Dapat diartikan bahwa manajemen sumber daya manusia merupakan keseluruhan proses penerapan fungsi-fungsi manajemen pada suatu organisasi.

Karyawan mempunyai peranan penting dalam menjalankan aktivitas organisasi, baik sebagai perencana, maupun sebagai pelaksana kegiatan dalam suatu organisasi. Tercapai atau tidaknya tujuan suatu organisasi yang telah ditetapkan sangat dipengaruhi oleh kinerja pegawai dalam melaksanakan tugas yang menjadi tanggung jawabnya.

Persaingan industri yang semakin ketat menuntut perusahaan untuk mengoptimalkan seluruh sumber daya yang dimiliki dalam menghasilkan produk berkualitas tinggi. Kualitas produk yang dihasilkan tidak terlepas dari peranan sumber daya manusia (SDM) yang dimiliki perusahaan. sumber daya dalam perusahaan seperti modal, mesin, dan material dapat bermanfaat bila ruang dan fungsi telah diolah oleh SDM (Tenaga Kerja).

Begitu juga halnya dengan $\mathrm{CV}$. YWN Motor Kampar yang bergerak dibidang penjualan alat sepeda motor. Pengawasan terhadap karyawan adalah faktor yang sangat diperhatikan, baik sehingga karyawan bisa mencapai prestasi kerja yang optimal dalam bentuk hasil kerja. Bahwa CV YWN Motor Kampar tidak memberikan kenaikan, THR, pembayaran insentif dan juga bonus pada 3 tahun terakhir, bahkan insentif dan juga bonus mengalami penurunan. Dari perubahan sistem tersebut maka muncul konflik intern antara karyawan dengan pihak perusahaan, yang akhirnya mempengaruhi kinerja karyawan itu sendiri.

Dan juga berdasarkan pengamatan yang telah dilakukan menunjukkan bahwa pengawasan yang ada di perusahaan ini tidak dilaksanakan dengan semestinya oleh pimpinan. Pengaruh pengawasan terhadap kinerja kerja karyawan menjadi 
sangat penting untuk dibahas. Hal ini dimaksud untuk melihat apakah dengan diadakannya pengawasan maka dapat berpengaruh terhadap peningkatan kierja karyawan pada perusahaan ini. Apabila ada pengawasan yang efektif dari pimpinan maka semangat kerja akan timbul dan para karyawan akan bekerja dengan rajin dengan disiplin yang tinggi dan bertanggung jawab sehingga kinerja dapat meningkat dengan sendirinya.

Selanjutnya Simamora (2007:442) mendefinisikan kompensasi sebagai berikut : "Imbalan finansial dan jasa nirwujud serta tunjangan yang diterima oleh para karyawan sebagai bagian dari hubungan kepegawaian". Menurut Hasibuan (2007:118) kompensasi adalah: Semua pendapatan yang berbentuk uang atau barang langsung atau tidak langsung yang diterima karyawan sebagai imbalan atas jasa yang diberikan pada perusahaan .Ada pembayaran keuangan langsung dalam bentuk upah, gaji, insentif, komisi, dan bonus, dan ada pembayaran yang tidak langsung dalam bentuk tunjangan keuangan seperti uang asuransi dan uang liburan yang dibayarkan oleh majikan. Dan kompensasi langsung merupakan imbalan jasa kepada pegawai yang diterima secara langsung, rutin atau periodik karena yang bersangkutan telah memberikan bantuan/ sumbangan untuk mencapai tujuan organisasi.

Sedangkan menurut Mathis \& Jackson (2011:118). Kompensasi adalah faktor yang mempengaruhi bagaimana dan mengapa orang-orang bekerja pada suatu organisasi dan bukan pada organisasi lainnya. Pengusaha harus cukup kompetitif dengan beberapa jenis kompensasi untuk mempekerjakan, mempertahankan, dan memberikan imbalan terhadap kinerja setiap individu didalam organisasi. Dalam bukunya Bangun (2012:255) Indikator kompensasi financial diantaranya yaitu: Upah/Gaji pokok. Imbalan langsung yang diterima setiap periode tertentu. Bonus, tambahan kompensasi langsung yang dikaitkan dengan kinerja perusahaan dan keuntungan perusahaan dan biasanya diberikan pertahun. Insentif, Sebagai penghargaan langsung untuk prestasi termasuk komisi bagi tenaga penjualan atau tenaga lainnya. Tunjangan, Yaitu imbalan tidak langsung yang diberikan kepada setiap karyawan sebagai hak atas keanggotaannya seperti asuransi, jaminan kesehatan, tunjangan hari raya.

Menurut Kadarisman (2012:171), pengawasan adalah fungsi di dalam manajemen fungsional yang harus dilaksanakan oleh setiap pimpinan semua unit/satuan kerja terhadap pelaksanaan pekerjaan atau pegawai yang melaksanakan sesuai dengan tugas pokoknya masing-masing. Menurut Marnis (2009:344), pengawasan adalah proses pemonitoran kegiatan organisasi untuk mengetahui apakah kinerja aktual sesuai dengan standar dan tujuan organisasi yang diharapkan.

Menurut Handoko (2011:359), pengawasan adalah proses untuk menjamin bahwa tujuan-tujuan organisasi dan manajemen tercapai. pengawasan merupakan sebagai proses dalam menetapkan ukuran kinerja dalam pengambilan tindakan yang dapat mendukung pencapaian hasil yang diharapkan sesuai dengan ukuran yang telah ditetapkan tersebut..

Adapaun tujuan pengawasan menurut Sukarna (2006:112), yaitu sebagai berikut : Untuk mengetahui jalannya pekerjaan lancar atau tidak; Untuk memperbaiki kesalah-kesalahn yang dibuat oleh karyawan dan mengusahakan pencegahan agar tidak terulang kembali kesalahan yang serupa atau timbul kesalahan baru; Untuk mengetahui apakah penggunaan budget yang telah ditetapkan dalam perencanaan/planning terarah kepada sasarannya dan sesuai dengan yang telah ditentukan; Untuk mengetahui apakah pelaksanaan biaya telah sesuai dengan program seperti yang telah ditetapkan dalam planning atau tidak; Untuk mengetahui hasil pekerjaan dengan

p.ISSN: $2407-800 X \quad$ e.ISSN: 2541-4356 
membandingkannya dengan apa yang telah ditetapkan dalam rencana (standar) perusahaan; Untuk mengetahui apakah pelaksanaan kerja sesuai dengan prosedur atau kebijaksanaan yang ditentukan.

Menurut Erni dan Saefullah (2006:12), fungsi pengawasan adalah : Mengevaluasi keberhasilan dan pencapaian tujuan serta target sesuai dengan indikator yang ditetapkan; Mengambil langkah klarifikasi dan koreksi atas penyimpangan yang mungkin ditemukan; Melakukan berbagai alternatif solusi atas berbagai masalah yang terkait dengan pencapaian tujuan perusahaan.

$$
\text { Adapun indikator pengawasan }
$$

menurut Handoko (2011:363) yaitu : Penetapan standar pelaksanaan/ perencanaan Tahap pertama dalam pengawasan adalah menetapkan standar pelaksanaan, standar mengandung arti sebagai suatu satuan pengukuran yang dapat digunakan sebagai patokan untuk penilaian hasil; Penentuan pengukuran pelaksanaan kegiatan.

Penetapan standar akan sia-sia bila tidak disertai berbagai cara untuk mengukur pelaksanaan kegiatan nyata. Tahap kedua ini menentukan pengukuran pelaksanaan kegiatan secara tepat. Pengukuran juga sebaiknya mudah dilaksanakan, tidak mahal, serta dapat diterangkan kepada karyawan. Pengukuran pelaksanaan kegiatan. Ada beberapa cara untuk melakukan pengukuran pelaksanaan yaitu Pengamatan, Laporan-laporan baik lisan ataupun tertulis, Metode-metode otomatis, Pengujian atau dengan pengambilan sampel. Perbandingan pelaksanaan dengan standar analisis penyimpangan. Tahap kritis dari proses pengawasan adalah membandingkan pelaksanaan nyata dengan pelaksanaan yang telah direncanakan atau standar yang telah ditetapkan. Kompleksitas sangat mungkin terjadi saat pengimpretasian penyimpangan. Penyimpanganpenyimpangan harus dianalisa agar dapat diketahui penyebab mengapa standar tidak dapat dicapai. Pengambilan tindakan koreksi. Bila hasil analisa menunjukkan adanya tindakan koreksi, tindakan iniharus diambil. Tindakan koreksi dapat diambil dalam berbagai bentuk. Standar mungkin diubah, pelaksanaan diperbaiki, atau keduanya dilakukan bersamaan.

Payaman (2011:2) mengartikan kinerja sebagai pencapaian hasil atas pelaksanaan tugas tertentu. Dijelaskan juga bahwa kinerja pegawai adalah tingkat pencapaian hasil kerja pegawai dalam rangka mewujudkan tujuan organisasi. Penjelasan ini sejalan dengan yang dikemukakan Siswanto (2009:231) bahwa kinerja adalah kemampuan dalam melaksanakan tugasnya yang didasarkan kecakapan, usaha dan kesempatan. Artinya, kinerja sangat erat hubungannya dengan kemampuan seseorang dalam melaksanakan tugas.

$$
\text { Menurut Hasibuan (2009:105) }
$$

bahwa kinerja merupakan suatu hasil kerja yang dicapai seseorang dalam menjalankan tugas-tugasnya yang dibebankan kepadanya yang didasarkan atas kecakapan, pengalaman, kesungguhan serta waktu. Prestasi kerja ini adalah gabungan dari tiga faktor penting, yaitu (1) kernampuan minat seseorang bekerja, (2) kernampuan dan penerimaan atas penjelasan delegasi tugas, dan (3) peran serta tingkat, motivasi seseorang pekerja. Semakin tinggi faktor di atas, maka semakin besar prestasi kerja pegawai yang bersangkutan.

Siswanto (2009:234) menjelaskan bahwa faktor-faktor yang mempengaruhi kinerja pegawai adalah pekerjaan yang menarik, upah yang baik, kemanan dan perlindungan dalam pekerjaan, penghayatan atas maksud dan makna pekerjaan, lingkungan atau suasana kerja yang baik, promosi dan pengembangan diri, merasa terlibat dalam kegiatan organisasi, kepemimpinan, dan disiplin kerja yang keras.

Payaman (2011:10) menjelaskan bahwa kinerja setiap orang dipengaruhi oleh banyak faktor yang dapat dikelompokkan pada 3 (tiga) kelompok, 
yaitu: (1) kompetensi individu seperti kemampuan dan keterampilan kerja melakukan kerja; (2) dukungan organisasi seperti ketersediaan sarana dan prasarana kerja, kepuasan kerja kompensasi dan kenyamanan lingkungan kerja; dan (3) dukungan manajemen seperti kepemimpinan, pengawasan dan lingkungan kerja.

Indikator kinerja menurut Sedarmayanti, (2009:319), adalah sebagai berikut: Kualitas, yaitu mutu yang harus dihasilkan (baik tidaknya), pengukuran kualitatif keluaran mencerminkan pengukuran tingkat keterampilan, kemampuan yaitu seberapa baik penyelesainnya; Inisiatif, yaitu Kesadaran untuk melaksanakan tugas dan tanggung jawab dengan baik, dan benar. Ketepatan waktu, yaitu sesuai tidaknya dengan waktu yang direncanakan. Pengukuran ketepatan waktu merupakan jenis khusus dari pengukuran kuantitatif yang menentukan ketepatan waktu penyelesaian suatu kegiatan; Kemampuan, yaitu kemampuan karyawan melakukan kegiatan dengan komitmen kerja yang tinggi; Komunikasi, yaitu interaksi anatara para karyawan dan juga dengan atasan ditempat kerja.

\section{METODE}

Penelitian ini di lakukan pada CV. YWN Motor kampar Kampar yang beralamat di Jalan Datok Tabano Kampar.Jenis dan sumber data dalam penelitian ini terdiri dari 2 (dua) jenis, yaitu : 1) Data Primer, yaitu data yang diperoleh secara langsung ditempat penelitian dengan hasil pengamatan penelitian pada CV YWN Motor Kampar yang berkaitan dengan permasalahan yang dihadapi. Adapun data primer yang dikumpulkan seperti wawancara langsung dengan karyawan tentang pengawasan kerja kepada karyawan CV YWN Motor Kampar. 2) Data Sekunder, yaitu data yang diperoleh untuk melengkapi dan menjelaskan masalah yaitu sumber data penulis peroleh dari bahan di perusahaan yang ada kaitannya dengan penelitian ini, selain itu pengumpulan data juga dilakukan dengan bahan-bahan bacaan atau literatur laporan serta tulisan-tulisan yang ada kaitannya.

Dalam pengumpulan data yang diperlukan untuk penelitian ini, maka penulis melakukan teknik pengumpulan data melalui kuesioner. Sedangkan teknik pengambilan sampel ditentukan secara sensus yaitu mengambil seluruh populasi yang digunakan sebagai sampel karena jumlah populasi < 100 (Suharsimi Arikunto, 2010:174). Sampel dalam penelitian ini yaitu sebanyak 32 orang.

Dalam menganlisis data yang diperoleh, penulis menggunakan metode kuantitatif dengan analisis regresi berganda, yaitu suatu cara yang dapat menjelaskan hasil penelitian yang ada dengan menggunakan persamaan rumus matematis dan menghubungkannya dengan teori yang ada, kemudian ditarik kesimpulan. Regresi linear berganda digunakan oleh peneliti, bila peneliti bermaksud meramalkan bagaimana keadaan (naik turunnya) variabel dependen (kriterium), bila dua atau lebih variabel indpenden sebagai faktor prediktor dimanipulasi (dinaik turunkan nilainya). Jadi analisis regresi berganda akan dilakukan bila jumlah variabelindependennya minimal dua (Sugiyono,(2010:243):

$\mathrm{Y}=\mathrm{a}+\mathrm{b} 1 \mathrm{x} 1+\mathrm{b} 2 \mathrm{x} 2$

Keterangan:

$\mathrm{Y}=$ Kinerja karyawan

$\mathrm{b}=$ Koefisien Regresi

$\mathrm{a}=$ Konstanta

$\mathrm{X} 1=$ Kompensasi Finansial

$\mathrm{X} 2=$ Pengawasan

\section{HASIL}

Pengujian hipotesis secara parsial bahwa pengaruh kompensasi financial (X1) terhadap kinerja karyawan ( Y ). Dari data diatas jika nilai $\mathrm{t}$ hitung dibandingkan dengan $\mathrm{t}$ tabel hasilnya adalah 2,207 > 2,042 dan nilai siginifikansi sebesar 0,03 < 0,05 artinya secara parsial kompensasi financial berpengaruh signifikan terhadap kinerja karyawan. Kemudian Pengaruh pengawasan (X2) terhadap kinerja karyawan ( Y ).

p.ISSN: 2407-800X e.ISSN: 2541-4356 
Dari data diatas jika nilai $t$ hitung dibandingkan dengan $t$ tabel hasilnya adalah $5,536>2,024$ dan nilai siginifikansi sebesar $0,00<0,05$ artinya secara parsial pengawasan berpengaruh signifikan terhadap kinerja karyawan.

Dari tabel ANOVA diperoleh nilai $\mathrm{F}$ sebesar 22,465 dengan nilai probabilitas (Sig.) $=0,000$, karena nilai sig $<0,05$ maka hasilnya adalah kompensasi financial dan pengawasan secara bersama-sama berpengaruh signifikan terhadap kinerja karyawan CV. YWN Motor kampar.

Pada penelilitan ini nilai Adjusted $\mathrm{R}$ Square dapat dilihat nilai Adjusted R Square sebesar 0,608 Artinya adalah bahwa sumbangan pengaruh kompensasi financial dan pengawasan secara bersama-sama berpengaruh terhadap kinerja karyawan $\mathrm{CV}$. YWN Motor Kampar adalah sebesar 60,8 \%.

\section{PEMBAHASAN}

Dari tabel ANOVA diperoleh nilai $\mathrm{F}$ sebesar 22,465 dengan nilai probabilitas (Sig.) $=0,000$, karena nilai sig $<0,05$ maka hasilnya adalah kompensasi financial dan pengawasan secara bersama-sama berpengaruh signifikan terhadap kinerja karyawan CV. YWN Motor Kampar. Dan sumbangan besaran kompensasi financial dan pengawasan secara bersama-sama berpengaruh terhadap kinerja karyawan sebesar $60,8 \%$.

Dan hasil penelitian ini sejalan dengan teori yang dikemukakan oleh Payaman (2011:10) menjelaskan bahwa kinerja setiap orang dipengaruhi oleh banyak faktor yang dapat dikelompokkan pada 3 (tiga) kelompok, yaitu: (1) kompetensi individu seperti kemampuan dan keterampilan kerja melakukan kerja; (2) dukungan organisasi seperti ketersediaan sarana dan prasarana kerja, kepuasan kerja, kompensasi dan kenyamanan suasana kerja; dan (3) dukungan manajemen seperti kepemimpinan, pengawasan dan lingkungan kerja.

\section{SIMPULAN}

Dari beberapa uraian hasil SPSS pembahasan penelitian maka penulis membuat kesimpulan sebagai berikut : Dari data diatas jika nilai $t$ hitung dibandingkan dengan $\mathrm{t}$ tabel hasilnya adalah 2,207 > 2,042 dan nilai siginifikansi sebesar $0,03<0,05$ artinya secara parsial kompensasi financial berpengaruh signifikan terhadap kinerja karyawan. Dari data diatas jika nilai $\mathrm{t}$ hitung dibandingkan dengan $\mathrm{t}$ tabel hasilnya adalah 5,536 > 2,024 dan nilai siginifikansi sebesar $0,00<$ 0,05 artinya secara parsial pengawasan berpengaruh signifikan terhadap kinerja karyawan. Dari tabel ANOVA diperoleh nilai $F$ sebesar 22,465 dengan nilai probabilitas (Sig.) $=0,000$, karena nilai sig $<0,05$ maka hasilnya adalah kompensasi financial dan pengawasan secara bersamasama berpengaruh signifikan terhadap kinerja karyawan CV. YWN Motor. Diketahui nilai Adjusted R Square sebesar 0,608 Artinya adalah bahwa sumbangan pengaruh kompensasi financial dan pengawasan secara bersama-sama berpengaruh terhadap kinerja karyawan CV. YWN Motor adalah sebesar 60,8 \%. Berdasar hasil SPSS maka model regresi linear berganda adalah :

$\mathrm{Y}=-9,374+0,329 \mathrm{X}_{1}+0,857 \mathrm{X}_{2}$

Dari Persamaan diatas nilai constant a sebesar -9,374 yang artinya pada saat kompensasi financial dan pengawasan tidak ada atau nol, maka kinerja karyawan CV. YWN Motor kurang dari 9,374 satuan. Sedangkan pengaruh kompensasi financial dan pengawasan adalah Positif, artinya setiap peningkatan kompensasi financial dan pengawasan akan diikuti peningkatan kinerja karyawan CV. YWN Motor. 


\section{DAFTAR RUJUKAN}

Arikunto, Suharsimi. 2010. Prosedur Penelitia., Rineka Cipta. Jakarta.

Bangun Wilson 2012 Manajemen Sumber Daya Manusia. Erlangga, Jakarta

Erni Tisnawati Sule, Kurniawan Saefullah 2007 Pengantar Manajemen, Kencana Jakarta.

Hasibuan, Malayu. 2007. Organisasi dan Motivasi. Bumi Aksara. Jakarta.

Hani T Handoko,2011 Manajemen Personalia dan Sumber Daya manusia, BPFEE Yogyakarta

Marnis. 2009. Pengantar Manajemen. Edisi Ketujuh. Panca Abdi Nurgama. Pekanbaru

Malthis, R.L dan Jackson, 2011 Manajemen Sumber Daya Manusia. Salemba Empat. Jakarta.

Muhammad, Kadarisman 2012, Manajemen Pengembangan Sumber Daya Manusia, Rajawali Pers. Jakarta.

Payaman Simanjuntak. 2011 Manajemen dan Evaluasi Kinerja. Jakarta: Lembaga Penerbit Fakultas Ekonomi Universitas Indonesia

Sedarmayanti. 2009 .Manajemen Sumber Daya Manusia. PT. Refika Aditama. Bandung.

Simamora Henry ,2007 Manajemen Sumber Daya Manusia, Jakarta: Penerbit STIE YKPN.

Sukarna, AS. 2006. Manajemen Pelayanan Umum di Indonesia. Bumi Aksara. Jakarta
Sugiyono. 2010. Metode Penelitian Administrasi.Alfabeta. Bandung.

Siswanto H Bejo 2009 , Pengantar
$\begin{gathered}\text { Manajemen } \\ \text { Jakarta }\end{gathered}$

